\title{
Genome-wide identification of genetic determinants for the cytotoxicity of perifosine
}

\author{
Wei Zhang,' Wanqing Liu,' Enrique Poradosu² and Mark J. Ratain ${ }^{1,3,4^{*}}$ \\ 'Section of Hematology/Oncology, Department of Medicine, The University of Chicago, Chicago, IL 60637, USA \\ ${ }^{2}$ Keryx Biopharmaceuticals, Inc., New York, NY 10022, USA \\ ${ }^{3}$ Committee on Clinical Pharmacology and Pharmacogenomics, The University of Chicago, Chicago, IL 60637, USA \\ ${ }^{4}$ Cancer Research Center, The University of Chicago, Chicago, IL 60637, USA \\ *Correspondence to: Tel: +1 773702 4400; Fax: +1 773702 3969; E-mail: mratain@medicine.bsd.uchicago.edu
}

Date received (in revised form): 17th June, 2008

\begin{abstract}
Perifosine belongs to the class of alkylphospholipid analogues, which act primarily at the cell membrane, thereby targeting signal transduction pathways. In phase I/II clinical trials, perifosine has induced tumour regression and caused disease stabilisation in a variety of tumour types. The genetic determinants responsible for its cytotoxicity have not been comprehensively studied, however. We performed a genome-wide analysis to identify genes whose expression levels or genotypic variation were correlated with the cytotoxicity of perifosine, using public databases on the US National Cancer Institute (NCl)-60 human cancer cell lines. For demonstrating drug specificity, the $\mathrm{NCl}$ Standard Agent Database (including I7I drugs acting through a variety of mechanisms) was used as a control. We identified agents with similar cytotoxicity profiles to that of perifosine in compounds used in the $\mathrm{NCl}$ drug screen. Furthermore, Gene Ontology and pathway analyses were carried out on genes more likely to be perifosine specific. The results suggested that genes correlated with perifosine cytotoxicity are connected by certain known pathways that lead to the mitogen-activated protein kinase signalling pathway and apoptosis. Biological processes such as 'response to stress', 'inflammatory response' and 'ubiquitin cycle' were enriched among these genes. Three single nucleotide polymorphisms (SNPs) located in CACNA2DI and EXOC4 were found to be correlated with perifosine cytotoxicity. Our results provided a manageable list of genes whose expression levels or genotypic variation were strongly correlated with the cytotoxcity of perifosine. These genes could be targets for further studies using candidate-gene approaches. The results also provided insights into the pharmacodynamics of perifosine.
\end{abstract}

Keywords: perifosine, cytotoxicity, $\mathrm{NCl}-60$, gene expression, genotype

\section{Introduction}

Perifosine (NSC639966; Figure 1) belongs to the class of phospholipid analogues or alkylphospholipids, which have anticancer activity in both in vitro (cell culture studies) and in vivo (animal modelbased studies) model systems. ${ }^{1,2}$ Functionally, perifosine resembles natural phospholipids and acts primarily at the cell membrane, thereby targeting signal transduction pathways. Perifosine has been shown to inhibit, or otherwise modify, signal transduction through a number of different pathways, including mitogen-activated protein kinase (MAPK) and Akt. $^{2-5}$ Preclinical studies suggest that perifosine inhibits protein kinase B/Akt phosphorylation and induces in vitro and in vivo cytotoxicity in cancer cell lines such as multiple myeloma 


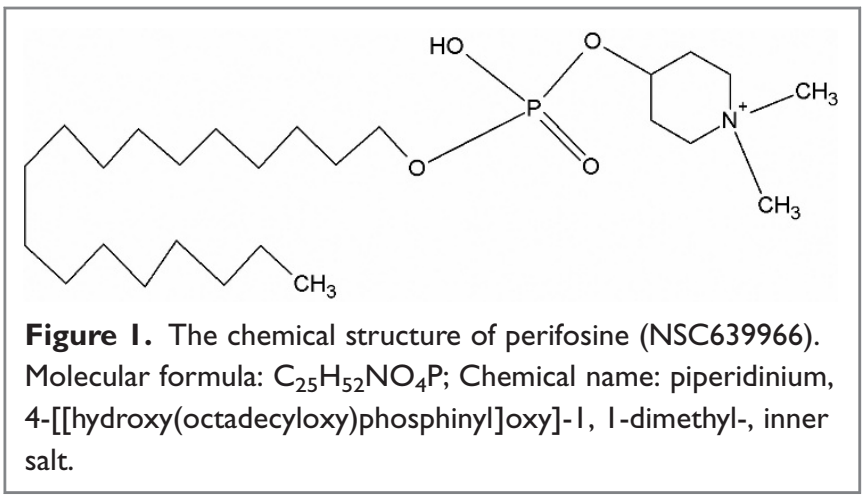

cells, ${ }^{4} \mathrm{HeLa}$ cells ${ }^{3}$ and prostate carcinoma cells. ${ }^{2}$ Clinical studies have focused on daily oral dosing (after a loading dose), with two partial responses noted in soft tissue sarcoma (STS) patients, including one patient each with chondrosarcoma and leiomyosarcoma, ${ }^{6,7}$ as well as patients with renal cell carcinomas. ${ }^{7}$ Furthermore, the phase II studies in STS patients were not designed to look for disease stabilisation, a potentially important endpoint for drugs targeting signal transduction pathways. ${ }^{8}$

The genetic determinants that are responsible for perifosine's activity have not been comprehensively studied, however. Traditional candidate-gene approaches require a priori knowledge and the selection of a small number of candidate genes for hypothesis testing, while an in silico genome-wide approach could be used to identify any associated genes as potential candidates in an unsupervised way. The US National Cancer Institute (NCI)-60 resources have allowed genome-wide studies using a panel of 60 human cancer cell lines. ${ }^{9}$ In addition to the genetic determinants, the NCI-60 resources also provide tools such as COMPARE ${ }^{10}$ to identify compounds that show correlated cytotoxic patterns with a particular agent. These compounds, for example, could be potential agents for enhancing the response to a candidate drug or as a substitute for that drug.

The NCI-60 human cancer cell lines have been used in anti-cancer drug screens conducted by the NCI since the late 1980s. ${ }^{9}$ The cell lines represent nine distinct tumour types: leukaemia, colon, lung, brain, renal, melanoma, ovarian, breast and prostate. The Developmental Therapeutics Program (DTP) at $\mathrm{NCI}^{11}$ has maintained a database for the cytotoxicity data, as represented by the $\mathrm{GI}_{50}$ (the concentration required to inhibit cell growth by 50 per cent) on $>40,000$ cytotoxic agents, including perifosine. ${ }^{12}$ A handful of gene expression datasets using high-throughput platforms such as the Affymetrix oligonucleotide microarrays and cDNA arrays of the untreated NCI-60 cell lines are now publicly available at the DTP/NCI website (Table 1). Recently, the NCI-60 cell lines were genotyped for $\sim 120,000$ single nucleotide polymorphism (SNP) markers using the Affymetrix Human 125K Mapping Array manufacturers details. ${ }^{13}$ By associating gene expression or SNP genotypes in untreated NCI-60 cell lines, investigators have been able to predict the chemosensitivity of various cytotoxic compounds. ${ }^{14-16}$ Here, we report a list of candidate genes whose expression levels or genotypic variation were found to be strongly correlated with the cytotoxicity of perifosine using these publicly available NCI-60 databases. The genes identified could be studied further using a candidate-gene approach. They also could provide new insights into the pharmacodynamics of perifosine.

\section{Materials and methods}

\section{Cytotoxicity data}

The 60 NCI-60 human cancer cell lines were originally exposed to $>40,000$ compounds at NCI/ NIH and outside laboratories. The growth inhibitory effects of each compound were measured for each cell line and reported as the $\mathrm{GI}_{50}$ (for details, see the DTP/NCI website ${ }^{17}$ ) and maintained in the DTP/NCI online databases. Cytotoxicity data on perifosine (NSC639966) and other agents were obtained as the normalised $-\log _{10}\left[\mathrm{GI}_{50}\right]$ values (released in September 2005). The NSC numbers and common names for the standard agents were retrieved from the DTP/NCI website.

\section{COMPARE analysis}

The COMPARE software ${ }^{10,18,19}$ maintained at the DTP/NCI, was used to screen $>40,000$ synthetic or natural compounds for agents that showed correlated cell growth $\left(\mathrm{GI}_{50}\right)$ patterns with that of perifosine. COMPARE generates rank-ordered lists of compounds based on the similarities of cytotoxicity 
Table I. $\mathrm{NCl}-60$ microarray expression datasets

\begin{tabular}{|c|c|c|c|c|}
\hline Dataset & Institution & Platform & $\begin{array}{l}\text { No. of } \\
\text { genes } \\
\text { on } \\
\text { chip }\end{array}$ & $\begin{array}{l}\text { No. of } \\
\text { genes } \\
\text { analysed }^{\mathrm{a}}\end{array}$ \\
\hline MP-6800 & $\begin{array}{l}\text { Millenium } \\
\text { Pharmaceuticals, } \\
\text { Inc. }\end{array}$ & $\begin{array}{l}\text { Affymetrix } \\
\text { Human } \\
6800\end{array}$ & 7,451 & 2,955 \\
\hline GL-U95 & Gene Logic, Inc. & $\begin{array}{l}\text { Affymetrix } \\
\text { U95 }\end{array}$ & 63,175 & 23,223 \\
\hline NP-U95 & $\begin{array}{l}\text { Novartis } \\
\text { Pharmaceuticals, } \\
\text { Inc. }\end{array}$ & $\begin{array}{l}\text { Affymetrix } \\
\text { U95A }\end{array}$ & 12,626 & 10,063 \\
\hline NS-cDNA $^{41,42}$ & $\begin{array}{l}\mathrm{NCl} \text { and } \\
\text { Stanford } \\
\text { University }\end{array}$ & $\begin{array}{l}\text { cDNA } \\
\text { array }\end{array}$ & 9,703 & 5,291 \\
\hline
\end{tabular}

${ }^{\mathrm{a}}$ Genes or probe sets that had missing data in more than six cell lines ( 10 per cent) were not included in the analysis datasets. $\mathrm{NCl}$; National Cancer Institute.

patterns. Every compound from one of several specially prepared databases is ranked for similarity of its in vitro cell growth pattern to the in vitro cell growth pattern of a selected seed or probe compound (ie perifosine). Top-ranking agents based on Pearson correlation coefficient $r$, whose $\mathrm{GI}_{50}$ patterns correlated with that of perifosine, were reported by the software. To control false correlations due to small sample size, the minimum number of cell lines in common for two compounds to be included in the calculation was 50 . We further set the cut-off for COMPARE analysis at $|r|=0.6$ (equivalent to nominal $p<0.000001$, assuming 40,000 compounds and $n=60$, Bonferroni corrected $p<0.05)$.

\section{NCI-60 microarray expression datasets}

The NCI-60 microarray expression datasets (released in August 2005) were downloaded from the DTP/ NCI Molecular Target Databases. ${ }^{20}$ These datasets comprise gene expression data on untreated NCI-60 cell lines using different microarray platforms (Table 1). Genes or probe sets that had missing data in more than six cell lines (10 per cent) were not included in the final analysis dataset.

\section{NCI-60 SNP genotyes}

The genotype calls for 125,937 SNPs in 58 NCI-60 cell lines were to be downloaded from the DTP/NCI website using the Affymetrix Human 125K Mapping array. ${ }^{13}$ We removed uninformative SNPs, such as those with identical genotypes across all cell lines or those with missing data in more than six cell lines (10 per cent). Only SNP markers with at least two data points per genotype were included in the association studies. This left 34,040 highly informative SNPs in the final analysis dataset. Three exploratory genetic models (additive, dominant, recessive) were used to evaluate the association between genotype and cytotoxicity. Given the genotypes of a SNP marker (AA, AB, $\mathrm{BB})$, the genotypes were encoded as $(\mathrm{AA}=0$, $\mathrm{AB}=1, \mathrm{BB}=2$ ) in the additive model, (AA/ $\mathrm{AB}=1, \mathrm{BB}=0)$ in the dominant model and $(\mathrm{AA} / \mathrm{AB}=0, \mathrm{BB}=1)$ in the recessive model.

\section{Identifying associated copy number alterations}

Data on copy number alterations in the NCI-60 cell lines as reported by Garraway and colleagues ${ }^{13}$ were downloaded from the DTP/NCI website. 
Table 2. Agents correlated with the $\mathrm{GI}_{50}$ values of perifosine, as reported by COMPARE $(r>0.6)$

\begin{tabular}{|lll|}
\hline NSC\# & $\boldsymbol{r}$ & Chemical name \\
\hline 605583 & 0.81 & Miltefosin C; choline, hexadecyl hydrogen phosphate, inner salt \\
\hline 643826 & 0.75 & Choline, hydroxide, 3-methoxy-2-[methyl(octadecyl)amino]propyl hydrogen phosphate, inner salt \\
\hline 643828 & 0.68 & Choline, hydroxide, 2-methoxy-3-[methyl(octadecyl)amino]propyl hydrogen phosphate, inner salt \\
\hline 324368 & 0.68 & Edelfosine; I-octadecyl-2-methylphosphorylcholine \\
\hline 643827 & 0.68 & Choline, hydroxide, 3-methoxy-I-[methyl(octadecyl)amino]-2-propyl hydrogen phosphate, inner salt \\
\hline 18268 & 0.65 & Actinomycin D \\
\hline $678 I 44$ & 0.62 & 4H-I,3,6,2-dioxazaphosphocinium, 4-hexadecyltetrahydro- 2,6,6-trimethyl-, bromide, 2-oxide \\
\hline $33759 I$ & 0.62 & ES I2H; choline, hydroxide, 3-(dodecyloxy)propyl hydrogen phosphate, inner salt \\
\hline 87222 & 0.62 & Actinomycin C3 \\
\hline 266763 & 0.61 & 2-Propenamide, \\
\hline 207895 & N-[2-(decylsulfinyl)-I-(hydroxymethyl)ethyl]-3-(I,2,3,4-tetrahydro-6-methyl-2,4-dioxo-5-pyrimidinyl)- \\
\hline
\end{tabular}

\section{Linear regression model}

We performed genome-wide associations between the gene expression (or genotype) and cytotoxicity data. Pearson correlation coefficients and the associated $p$-values were computed using a linear regression model, which was implemented as the $\mathrm{lm}$ function in the R Statistical Package. ${ }^{21}$ Specifically, the cytotoxicity, as represented by $-\log _{10}\left[\mathrm{GI}_{50}\right]$, was modelled as dependent on either gene expression or genotype. To adjust for multiple tests, the false discovery rate (FDR) was controlled using the Benjamini and Hochberg step-up FDR procedure ${ }^{22}$ $\left(\mathrm{FDR}_{\mathrm{BH}}\right)$. An FDR cut-off of 10 per cent was used to identify candidates for further analyses.

\section{Associations with standard agents}

Associations between the identified genes and the cytotoxicity data on the 171 anti-cancer agents in the NCI Standard Agent Database ${ }^{23}$ were performed to evaluate perifosine specificity for our gene list. The standard agents cover a variety of mechanisms, besides being phospholipid analogues, and were originally determined by Boyd. ${ }^{24}$ The same cut-off $\left(\right.$ FDR $\left._{\mathrm{BH}}<0.10\right)$ was used to determine if an identified gene was associated significantly with any standard agents. The genes that showed no significant associations with any of the 171 standard agents using any dataset were denoted 'perifosine specific'. Genes that showed associations with any of the 171 standard agents using any dataset were denoted 'non-specific'.

\section{Gene ontology and pathway analyses}

We used Onto-Express and Pathway-Express ${ }^{25-27}$ to search enriched biological processes and known physiological pathways among the perifosinespecific genes from the Gene Ontology $(\mathrm{GO})^{28}$ and Kyoto Encyclopaedia of Genes and Genomes (KEGG) databases. ${ }^{29,30}$ GO terms or KEGG pathways that were over-represented relative to the corresponding analysis sets (two hits or more, binomial test at $\left.\mathrm{FDR}_{\mathrm{BH}}<0.05\right)$ were called 'enriched' in our gene list.

\section{STS expression database}

The identified perifosine-specific genes were queried against a STS expression database, which characterised eight gastrointestinal stromal tumours, eight monophasic synovial sarcomas, four liposarcomas, one myxoid, 11 leiomyosarcomas, eight malignant fibrous histiocytomas and two benign peripheral nerve sheath tumours (Schwannoma). ${ }^{31}$ 
Table 3a. Genes with expression levels specifically associated with the cytotoxicity of perifosine $($ FDR $\mathrm{BH}<0.10)$

\begin{tabular}{|c|c|c|c|c|}
\hline Gene symbol & Gene title & $r^{a}$ & $p$ & Response \\
\hline \multicolumn{5}{|l|}{ GL-U95 } \\
\hline REG4 & $\begin{array}{l}\text { Regenerating islet-derived family, } \\
\text { member } 4\end{array}$ & -0.58 & I.3E-06 & Sensitivity \\
\hline SLCO4AI & $\begin{array}{l}\text { Solute carrier organic anion } \\
\text { transporter family, member } 4 \mathrm{AI}\end{array}$ & -0.52 & $2.3 \mathrm{E}-05$ & Sensitivity \\
\hline RPLI8A & Ribosomal protein LI8a & -0.50 & 4.7E-05 & Sensitivity \\
\hline OAZ2 & Ornithine decarboxylase antizyme 2 & 0.53 & I.6E-05 & Resistance \\
\hline DZIP3 & Zinc finger DAZ-interacting protein 3 & 0.58 & I.5E-06 & Resistance \\
\hline \multicolumn{5}{|l|}{ NP-U95 } \\
\hline STK39 & $\begin{array}{l}\text { Serine threonine kinase } 39 \text { (STE20/ } \\
\text { SPSI homologue, yeast) }\end{array}$ & -0.48 & I.2E-04 & Sensitivity \\
\hline FAM $32 A$ & $\begin{array}{l}\text { Family with sequence similarity } 32 \text {, } \\
\text { member A }\end{array}$ & -0.46 & $2.5 \mathrm{E}-04$ & Sensitivity \\
\hline MAPKAPKЗ & $\begin{array}{l}\text { Mitogen-activated protein } \\
\text { kinase-activated protein kinase } 3\end{array}$ & -0.45 & $3.0 \mathrm{E}-04$ & Sensitivity \\
\hline RAB8A & RAB8A, member Ras oncogene family & -0.44 & 4.7E-04 & Sensitivity \\
\hline STKI IB & $\begin{array}{l}\text { Serine/threonine kinase } 17 \mathrm{~b} \\
\text { (apoptosis-inducing) }\end{array}$ & -0.44 & $5.8 \mathrm{E}-04$ & Sensitivity \\
\hline TCF3 & $\begin{array}{l}\text { Transcription factor } 3 \text { (E2A } \\
\text { immunoglobulin enhancer binding } \\
\text { factors EI2/E47) }\end{array}$ & -0.44 & $5.8 \mathrm{E}-04$ & Sensitivity \\
\hline PARP4 & $\begin{array}{l}\text { Poly (ADP-ribose) polymerase family, } \\
\text { member } 4\end{array}$ & -0.43 & 6.IE-04 & Sensitivity \\
\hline PSMA2 & $\begin{array}{l}\text { Proteasome (prosome, macropain) } \\
\text { subunit, alpha type, } 2\end{array}$ & -0.43 & $6.3 \mathrm{E}-04$ & Sensitivity \\
\hline DGKE & Diacylglycerol kinase, epsilon 64 kDa & -0.43 & $6.9 \mathrm{E}-04$ & Sensitivity \\
\hline PVTI & $\begin{array}{l}\text { Pvtl oncogene homologue, MYC } \\
\text { activator (mouse) }\end{array}$ & 0.42 & I.0E-03 & Resistance \\
\hline ELOVL2 & $\begin{array}{l}\text { Elongation of very long chain fatty } \\
\text { acids (FENI/Elo2, SUR4/Elo3, } \\
\text { yeast)-like } 2\end{array}$ & 0.42 & $9.5 \mathrm{E}-04$ & Resistance \\
\hline SMARCA3 & $\begin{array}{l}\text { SWI/SNF-related, matrix-associated, } \\
\text { actin-dependent regulator of } \\
\text { chromatin, subfamily a, member } 3\end{array}$ & 0.42 & $9.3 \mathrm{E}-04$ & Resistance \\
\hline USP6 & TLI32 protein & 0.43 & 7.IE-04 & Resistance \\
\hline IGFIR & Insulin-like growth factor I receptor & 0.44 & $5.3 \mathrm{E}-04$ & Resistance \\
\hline
\end{tabular}


Table 3a. Continued

\begin{tabular}{|c|c|c|c|c|}
\hline Gene symbol & Gene title & $r^{a}$ & $p$ & Response \\
\hline NFATC4 & $\begin{array}{l}\text { Nuclear factor of activated T-cells, } \\
\text { cytoplasmic, calcineurin-dependent } 4\end{array}$ & 0.44 & $5.4 \mathrm{E}-04$ & Resistance \\
\hline POU4FI & $\begin{array}{l}\text { POU domain, class } 4 \text {, transcription } \\
\text { factor I }\end{array}$ & 0.44 & 5.IE-04 & Resistance \\
\hline PDLIM3 & PDZ and LIM domain 3 & 0.44 & $5.0 \mathrm{E}-04$ & Resistance \\
\hline CBS & Cystathionine beta-synthase & 0.44 & 4.4E-04 & Resistance \\
\hline$A R M C X 2$ & Armadillo repeat containing, X-linked 2 & 0.45 & $3.9 \mathrm{E}-04$ & Resistance \\
\hline OPHNI & Oligophrenin I & 0.46 & $2.5 \mathrm{E}-04$ & Resistance \\
\hline ZNF609 & Zinc finger protein 609 & 0.46 & $2.3 \mathrm{E}-04$ & Resistance \\
\hline ATNI & Atrophin I & 0.47 & I.5E-04 & Resistance \\
\hline DZIP3 & Zinc finger DAZ-interacting protein 3 & 0.48 & I.3E-04 & Resistance \\
\hline PPBPL2 & Pro-platelet basic protein-like 2 & 0.49 & $9.3 \mathrm{E}-05$ & Resistance \\
\hline MPDZ & Multiple PDZ domain protein & 0.53 & I.3E-05 & Resistance \\
\hline SKIV2L & $\begin{array}{l}\text { Superkiller viralicidic activity 2-like } \\
\text { (Saccharomyces cerevisiae) }\end{array}$ & 0.56 & $4.6 \mathrm{E}-06$ & Resistance \\
\hline GABRG3 & $\begin{array}{l}\text { Gamma-aminobutyric acid (GABA) A } \\
\text { receptor, gamma } 3\end{array}$ & 0.60 & 4.9E-07 & Resistance \\
\hline \multicolumn{5}{|l|}{ NS-cDNA } \\
\hline ATF2 & Activating transcription factor 2 & -0.56 & $4.8 \mathrm{E}-06$ & Sensitivity \\
\hline TRA2A & Transformer-2 alpha & -0.44 & 8.3E-04 & Sensitivity \\
\hline ETS2 & $\begin{array}{l}\text { V-ets erythroblastosis virus E26 } \\
\text { oncogene homologue } 2 \text { (avian) }\end{array}$ & -0.44 & $5.3 \mathrm{E}-04$ & Sensitivity \\
\hline UBE2D3 & $\begin{array}{l}\text { Ubiquitin-conjugating enzyme E2D } 3 \\
\text { (UBC4/5 homologue, yeast) }\end{array}$ & -0.42 & 8.5E-04 & Sensitivity \\
\hline ANP32A & $\begin{array}{l}\text { Acidic (leucine-rich) nuclear } \\
\text { phosphoprotein } 32 \text { family, member A }\end{array}$ & 0.49 & $1.6 \mathrm{E}-04$ & Resistance \\
\hline
\end{tabular}

that a gene is correlated with resistance, while a negative $r$-value indicates that a gene is correlated with sensitivity.

Genes differentially expressed among different sarcomas were provided by the database using significance analysis of microarrays (SAM). ${ }^{32}$

\section{Results}

\section{COMPARE analysis}

At $p<0.05$ after Bonferroni correction, the COMPARE software ${ }^{10,18}$ identified 24 agents with positive correlation with the cytotoxicity pattern of perifosine. By contrast, no agents with significant negative correlation were identified. Table 2 shows some top-ranking agents $(r>0.6)$ with wellcharacterised chemical names. Among them, some clearly belong to the same drug class as perifosine: miltefosine (NSC605583, $r=0.81$ ) and edelfosine (NSC324368, $r=0.68$ ). Edelfosine was further used as a representative of phospholipid analogues 
Table 3b. SNPs associated with the cytotoxicity of perifosine $\left(\mathrm{FDR}_{\mathrm{BH}}<0.10\right)$

\begin{tabular}{|clllll}
\hline dbSNP & $\begin{array}{l}\text { Gene } \\
\text { locus }\end{array}$ & Location & $\boldsymbol{p}$ & Model \\
\hline rs4236669 & CACNA2DI & Intron & 0.64 & $2.8 \mathrm{E}-07$ & Recessive \\
\hline rsI468400 & CACNA2DI & Intron & 0.62 & $8.8 \mathrm{E}-07$ & Recessive \\
\hline rsI345938 & EXOC4 & Intron & 0.58 & $2.6 \mathrm{E}-06$ & Recessive \\
\hline
\end{tabular}

adbSNP Build 126 (May, 2006).

to verify the associations detected from perifosine (Supplementary Table 1).

\section{Genes with expression associated with perifosine cytotoxicity and GO and pathway analyses}

Table 3a lists the perifosine-specific genes identified from the microarray expression datasets. The nonspecific genes are listed in Supplementary Table 2. The GO and pathway analyses were then carried out to find any enriched biological processes and known KEGG pathways among the perifosinespecific genes (Table 4).

Table 4. Enriched Gene Ontology biological processes among the perifosine-specific genes

\begin{tabular}{|llll|}
\hline GO ID & Process & P & $\begin{array}{l}\text { Gene } \\
\text { symbol }\end{array}$ \\
\hline NP-U95 & & & \\
\hline GO:0006950 & Response to stress & $3.8 \mathrm{E}-04$ & $\begin{array}{l}\text { STK39 } \\
\text { MAPKAPK3 }\end{array}$ \\
\hline GO:00065II & $\begin{array}{l}\text { Ubiquitin-dependent } \\
\text { protein catabolism }\end{array}$ & $7.9 \mathrm{E}-04$ & $\begin{array}{l}\text { PSMA2 } \\
\text { USP6 }\end{array}$ \\
\hline GO:0006954 & $\begin{array}{l}\text { Inflammatory } \\
\text { response }\end{array}$ & $4.3 \mathrm{E}-03$ & $\begin{array}{l}\text { NFATC4 } \\
\text { PARP4 }\end{array}$ \\
\hline GO:00065I2 & Ubiquitin cycle & $6.5 \mathrm{E}-03$ & $\begin{array}{l}\text { DZIP3 } \\
\text { USP6 }\end{array}$ \\
\hline GO:0006366 & $\begin{array}{l}\text { Transcription from } \\
\text { RNA polymerase II } \\
\text { promoter }\end{array}$ & $7.8 \mathrm{E}-03$ & PPBPL2 \\
\hline NS-cDNA & NFATC4 \\
\hline GO:0006355 & $\begin{array}{l}\text { Regulation of } \\
\text { transcription, } \\
\text { DNA-dependent }\end{array}$ & $5.6 \mathrm{E}-03$ & EST2 ATF2 \\
\hline & & & \\
\hline
\end{tabular}

At $\mathrm{FDR}_{\mathrm{BH}}<0.10$, no genes were associated with perifosine cytotoxicty using the MP-6800 dataset, although at a more lenient cutoff $\left(\mathrm{FDR}_{\mathrm{BH}}<0.25\right)$, one gene, FABP5 (encoding fatty acid binding protein 5), could be described as being significantly correlated with the sensitivity response to perifosine. The expression of FABP5 was denoted as non-specific, as it was also associated with one standard agent. For the two Affymetrix U95 series of microarray datasets (GL-U95 and NP-U95), one gene, DZIP3 (encoding zinc finger DAZ-interacting protein 3), was correlated with the resistance response to perifosine using both datasets $\left(F_{D R}<0.10\right)$. DZIP3 was denoted as perifosine specific, as it showed no associations with any standard agents. In total, ten genes were found to be correlated with perifosine cytotoxicity $\left(\mathrm{FDR}_{\mathrm{BH}}<0.10\right)$ using the GL-U95 dataset: five each with sensitivity and resistance. Of these, five did not show associations with any standard agents. The GO biological process 'ubiquitin cycle' was enriched among all ten genes (two hits or more, binomial test at $\mathrm{FDR}_{\mathrm{BH}}<0.05$ ); however, it was not significant among the five perifosine-specific genes. No KEGG pathways were enriched among the identified genes. By contrast, 79 genes were found to be correlated with perifosine cytotoxicity $\left(\mathrm{FDR}_{\mathrm{BH}}<0.10\right)$ in the NP-U95 dataset. Among them, 30 genes were correlated with sensitivity, while 49 genes were correlated with resistance. Five GO biological processes were enriched among the 27 perifosine-specific genes (two hits or more, binomial test, FDR $_{\mathrm{BH}}<0.05$ ). No KEGG pathways were enriched among the identified genes. Using the NS-cDNA dataset, 23 genes were identified, with significant associations with perifosine cytotoxicity $\left(\mathrm{FDR}_{\mathrm{BH}}<0.10\right)$. 
Among them, 12 genes were correlated with sensitivity and 11 genes were correlated with resistance. One GO biological process, 'DNA-dependent regulation of transcription', was enriched among the five perifosine-specific genes. No KEGG pathways were enriched among the identified genes.

\section{SNPs associated with perifosine cytotoxicity}

Three SNPs under the recessive model were found to be significantly correlated with the resistance response to perifosine $\left(\mathrm{FDR}_{\mathrm{BH}}<0.10\right.$; Table $3 \mathrm{~b}$, Figure 2). These included two SNPs located in the introns of CACNA2D1 (calcium channel, voltagedependent, alpha 2/delta subunit 1). The third SNP is located in an intron of EXOC4 (exocyst complex component 4). Using both additive and dominant models, these three SNPs did not show significant associations with any standard agents. By contrast, rs1468400 in CACNA2D1 was correlated with one standard agent under the recessive model.

\section{Copy number alterations and perifosine cytotoxicity}

At $\mathrm{FDR}_{\mathrm{BH}}<0.10$, no copy number alterations or gene amplifications were found to be correlated with perifosine cytotoxicity.

\section{Querying gene expression patterns in STS cells}

Perifosine-specific genes in Table 3 a were queried against the STS expression database. ${ }^{31}$ Genes that are either up- or downregulated in each type of tumour are listed in Supplementary Table 3. Six genes (STK17B, IGF1R, POU4F1, CBS, MPDZ, EST2) were included in the database. With the exception of EST2, the other five genes were found to be up-or downregulated in certain STS cells.

\section{Discussion}

We performed a genome-wide analysis to identify genes whose expression levels were significantly

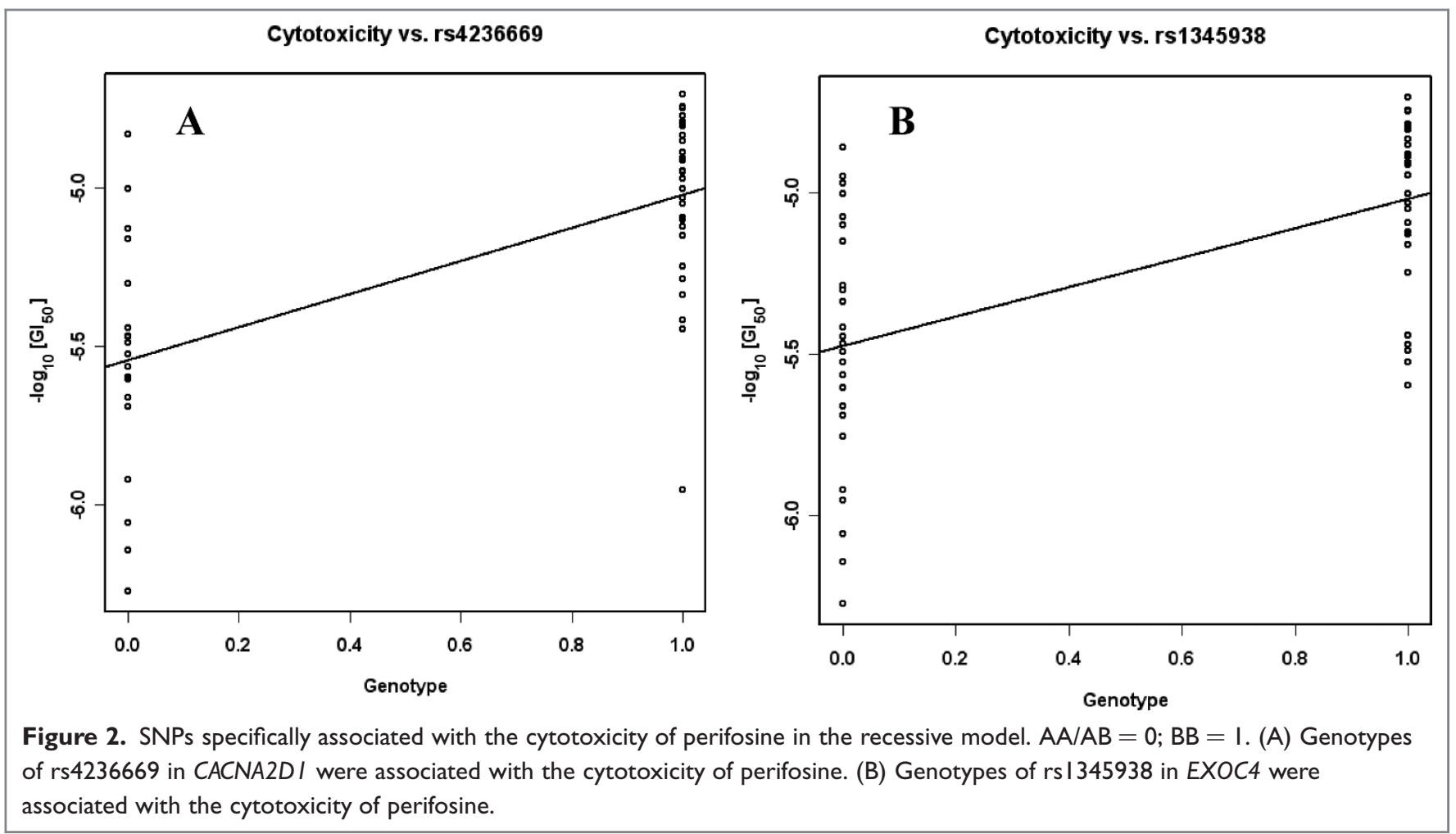


associated with perifosine's activity, as represented by its cytotoxicity $\left(\mathrm{GI}_{50}\right)$. Four independent gene expression datasets of untreated NCI-60 cancer cell lines (Table 1), using different microarray platforms, were used to evaluate the association between cytotoxcity and gene expression. We further focused on the identified genes that are more likely to be perifosine specific (Table 3). Previous studies, using traditional candidategene approaches, have suggested that perifosine inhibits, or otherwise modifies, signal transduction through a number of different pathways, including MAPK and Akt. $^{2-4}$ An in silico genome-wide scan without a priori knowledge in this work provided more candidate genes in an unsupervised way.

The use of COMPARE ${ }^{10,18}$ allowed us to identify compounds that have similar cell growth patterns with perifosine (Table 2). To limit the effects due to factors such as small sample size and multiple comparisons, we took measures to control potential false positives. Compounds including those belonging to the same drug class as perifosine (such as miltefosine and edelfosine) were among the top-ranking agents with strong positive correlation coefficients $(r>0.6, p<0.05$ after Bonferroni correction). Not surprisingly, a majority of the perifosine-specific genes were also significantly associated (nominal $p<0.05$ ) with edelfosine, which was used to represent phospholipid analogues (Supplementary Table 1). The remaining few genes showed at least marginal associations (nominal $p<0.10$ ) with edelfosine. This suggests that our list of perifosine-specific genes also contains a set of common genes that determines the pharmacodynamics of this drug class. To our knowledge, this is the most comprehensive list of associated genes for phospholipid analogues. The COMPARE program also retrieved drugs acting through different mechanisms (Table 2). The shared cytotoxicity profiles could be explained by the common pathways between these drugs and perifosine. For example, the correlation with actinomycin, which inhibits transcription by binding DNA at the transcription initiation complex and preventing elongation by
RNA polymerase, ${ }^{33}$ could be explained via general transcriptional modulation (Table 4).

We wanted to know the interactions among the perifosine-specific genes with known biological processes or pathways. Searches against the GO and KEGG databases identified six biological processes that were enriched among the perifosine-specific genes (Table 4). Among them, the biological process of the ubiquitin cycle was identified with DZIP3 and USP6. Notably, DZIP3 was significantly associated with resistance to perifosine, using two of the Affymetrix U95 series of arrays (Table 3a). The function of DZIP3, a ubiquitin ligase,${ }^{34}$ in the pharmacodynamics of perifosine has not been investigated, although, given the potential of ubiquitin ligases as anti-cancer targets, ${ }^{35,36}$ DZIP3 and the role of ubiquitin-dependent protein degradation could be an interesting candidate for further studies. The perifosine-specific genes also over-represented such biological processes as 'response to stress' and 'inflammatory response', which are more evidently related to drug response. Although no particular known KEGG pathways were found to be enriched among the perifosine-specific genes, many of these genes could be connected by a network of known physiological pathways (Figure 3) which have interactions with perifosine through known mechanisms that lead to the MAPK signalling pathway and apoptosis. For example, perifosine can affect the phosphatidylinositol signalling pathway, Akt signalling pathway and MAPK signalling pathway. ${ }^{37,38}$ Some of our identified perifosine-specific genes are known to be involved in these pathways; for example, DGKE (the phosphatidylinositol signalling pathway) and MAPKAPK3 (the MAPK signalling pathway). Furthermore, the gene product of $D G K E$ is involved in the phosphatidylinositol signalling system pathway and interacts with the phosphatidylinositol 3-kinase/phosphatase and tensin homologue deleted on chromosome 10 (PTEN)/ Akt pathways, ${ }^{30}$ suggesting its potential role in the perifosine response. The connected pathways can be divided into three categories: ${ }^{29}$ cell communication (tight junction, adherens junction and focal adhesion); immune systems ( $\mathrm{T} / \mathrm{B}$ cell receptor 


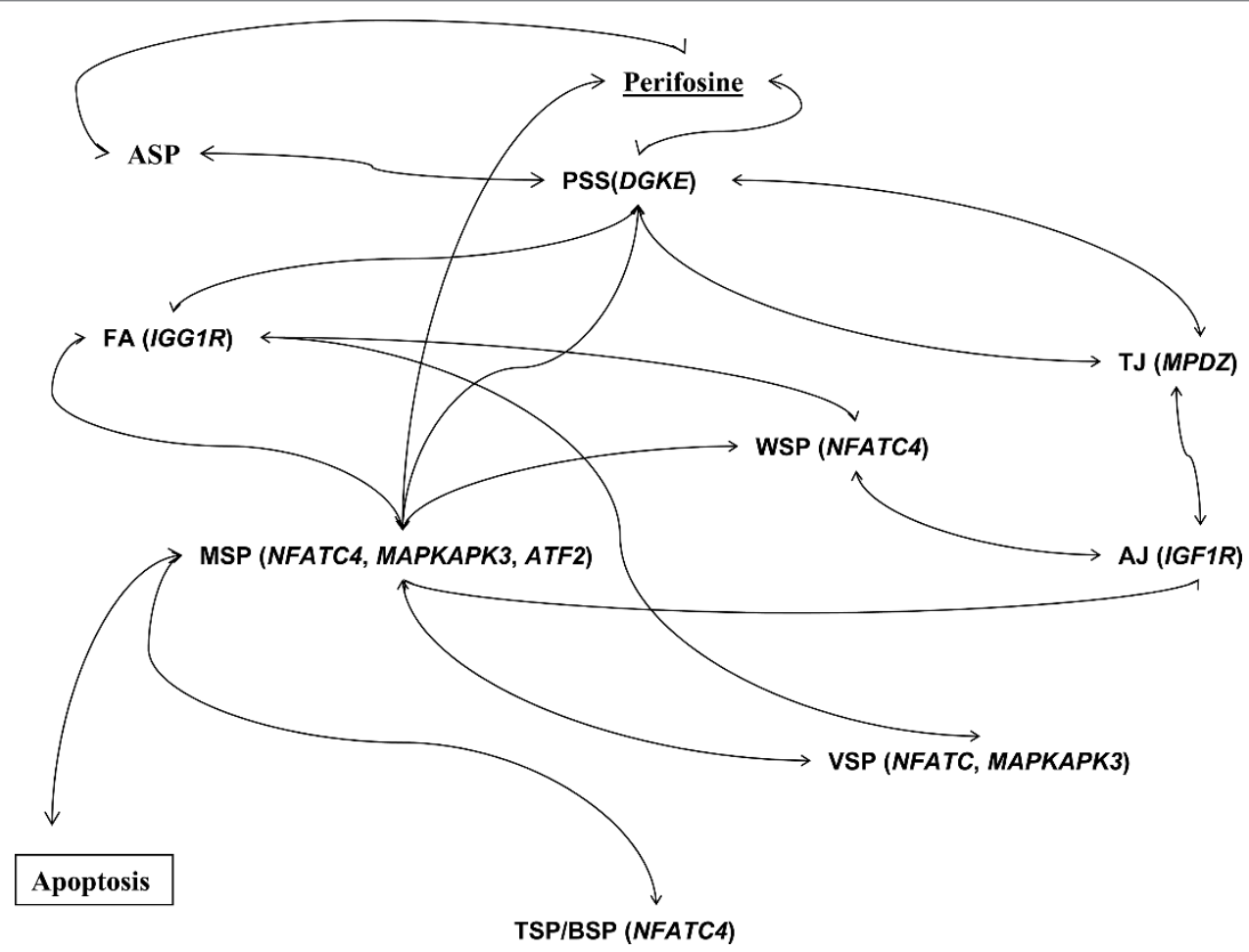

Figure 3. Some perifosine-specific genes are connected by common pathways leading to MAPK signalling pathway and apoptosis. Signal transduction pathways: ASP, Akt signalling pathway; PSS, phosphatidylinositol signalling system; WSP: Wnt signalling pathway; VSP, vascular endothelial growth factor signalling pathway; MSP, MAPK signalling pathway. Cell communication pathways: TJ, tight junction; AJ, adherens junction; FA, focal adhesion. Immune systems: TSP, T-cell receptor signalling pathway; BSP, B-cell receptor signalling pathway. The relationships among pathways were retrieved from the KEGG database (Release 45.0, January I, 2008).

signalling pathways); and signal transduction (MAPK, Wnt, vascular endothelial growth factor and phosphatidylinositol signalling pathways). Given the fact that perifosine, as well as edelfosine, significantly affects the pathway of extrinsic apoptosis, ${ }^{38-}$ 40 our findings showed that while perifosine was involved in such pathways as the MAPK and phosphatidylinositol signalling pathways that can lead to apoptosis, ${ }^{2-4}$ it could also influence other interconnected pathways, such as those in cell communication.

Variation in DNA sequence is partially responsible for gene expression; ${ }^{41,42}$ therefore, we performed an association test between SNP genotypes $^{13}$ and the cytotoxicity of perifosine. Different models (additive, dominant and recessive) were used to explore the genetic relationships between genotypes and cytotoxicity. Two SNPs (rs4236669 in CACNA2D1 and rs1345938 in
EXOC4) showed strong perifosine-specific associations under the recessive model (Figure 2). Since the expression of CACNA2D1 was not found to be significantly correlated with perifosine cytotoxicity, the relationship between gene expression and its genotypes is not straightforward. Given that CACNA2D1 is involved in the MAPK signalling pathway, ${ }^{29}$ however, these SNPs could be interesting candidates for further studies.

Studies have shown that alkylphospholipids are a class of anti-cancer agents that perturb signal transduction pathways through inhibition of MAPK and Akt phosphorylation. ${ }^{2-4}$ These drugs have shown consistent clinical anti-cancer activity, but their systemic application has been limited by toxicity. Therefore, one impact of our list of genes could be to help to identify better targeted cancer types for perifosine. One potential candidate, for example, could be multiple myeloma, given the 
fact that the PSMA2 gene (associated with the sensitivity response to perifosine; Table 3a) was found to be highly upregulated in multiple myeloma cells. ${ }^{43}$ In fact, perifosine activity has been reported in myeloma preclinically., ${ }^{4,39} \mathrm{~A}$ recent multicentre phase II study of perifosine alone and in combination with dexamethasone for patients with relapsed or relapsed/refractory multiple myeloma suggested promising activity (eg stabilisation of disease) as combination therapy, with manageable toxicity. ${ }^{44}$ Our results thus warrant further clinical trials for this tumour type. There is some evidence of perifosine having activity in STS, with responses reported in chondrosarcoma and leiomyosarcoma. ${ }^{6,7}$ Based on these studies, continued assessment of perifosine in STS also appears to be warranted. Given the heterogeneity of STS, it is a plausible hypothesis that there is an identifiable subset of tumours that will respond to this agent. ${ }^{45}$ A search against a STS expression database $^{31}$ further indicated that a type of leiomyosarcomas that does not express calponin showed the best correlated pattern of gene expression with our perifosine-specific genes (Supplementary Table 4). For example, STK17B (associated with the sensitivity response to perifosine; Table 3a) is significantly upregulated in this tumour type, while POU4F1 and MPDZ (associated with the resistance response to perifosine; Table 3a) are significantly downregulated in this tumour type, suggesting that this type of leiomyosarcoma could be a better target for perifosine. As the available STS expression dataset contains only $\sim 5,000$ genes, ${ }^{31}$ a more comprehensive dataset could provide more insights.

In summary, we used the public NCI-60 resources to identify a list of genes potentially relevant to the cytotoxicity of perifosine. Although there were some limitations; such as the gene coverage of the current microarray platforms, relatively small sample size of 60 cell lines and severity of multiple comparisons, our results not only confirmed that perifosine is involved in some known pathways (eg MAPK signalling) that can lead to apoptosis, but also suggested that it could influence some new candidate genes and pathways. Our unsupervised in silico analyses, therefore, could provide targeted candidates that are globally associated with the perifosine response for further studies.

\section{Acknowledgments}

This research was supported by a grant from Keryx Biopharmaceuticals, Inc., New York. The authors declare competing financial interests. E.P. is an employee of Keryx Biopharmaceuticals, Inc., New York. His employment with Keryx could be construed as a conflict of interest because he may indirectly benefit from sales of their products.

\section{References}

1. Berdel, W.E., Bausert, W.R., Fink, U. et al. (1981), 'Anti-tumor action of alkyl-lysophospholipids (Review)', Anticancer Res. Vol. 1, pp. 345-352.

2. Kondapaka, S.B., Singh, S.S., Dasmahapatra, G.P. et al. (2003), 'Perifosine, a novel alkylphospholipid, inhibits protein kinase B activation', Mol. Cancer Ther. Vol. 2, pp. 1093-1103.

3. Ruiter, G.A., Zerp, S.F, Bartelink, H. et al. (2003), 'Anti-cancer alkyllysophospholipids inhibit the phosphatidylinositol 3-kinase-Akt/PKB survival pathway', Anticancer Drugs Vol. 14, pp. 167-173.

4. Hideshima, T., Catley, L., Yasui, H. et al. (2006), 'Perifosine, an oral bioactive novel alkylphospholipid, inhibits Akt and induces in vitro and in vivo cytotoxicity in human multiple myeloma cells', Blood Vol. 107, pp. $4053-4062$.

5. Ruiter, G.A., Zerp, S.F., Bartelink, H. et al. (1999), 'Alkyl-lysophospholipids activate the SAPK/JNK pathway and enhance radiation-induced apoptosis', Cancer Res. Vol. 59, pp. 2457-2463.

6. Bailey, H.H., Mahoney, M.R., Ettinger, D.S. et al. (2006), 'Phase II study of daily oral perifosine in patients with advanced soft tissue sarcoma', Cancer Vol. 107, pp. 2462-2467.

7. Van Ummersen, L., Binger, K., Volkman, J. et al. (2004), 'A phase I trial of perifosine (NSC 639966) on a loading dose/maintenance dose schedule in patients with advanced cancer', Clin. Cancer Res. Vol. 10, pp. $7450-7456$.

8. Michaelis, L.C. and Ratain, M.J. (2006), 'Measuring response in a post-RECIST world: From black and white to shades of grey', Nat. Rev. Cancer Vol. 6, pp. 409-414.

9. Shoemaker, R.H. (2006), 'The NCI60 human tumour cell line anticancer drug screen', Nat. Rev. Cancer Vol. 6, pp. 813-823.

10. Zaharevitz, D.W., Holbeck, S.L., Bowerman, C. et al. (2002), 'COMPARE: A web accessible tool for investigating mechanisms of cell growth inhibition', J. Mol. Graph. Model. Vol. 20, pp. 297-303.

11. http://dtp.nci.nih.gov.

12. Paull, K.D., Shoemaker, R.H., Hodes, L. et al. (1989), 'Display and analysis of patterns of differential activity of drugs against human tumor cell lines: Development of mean graph and COMPARE algorithm', J. Natl. Cancer Inst. Vol. 81, pp. 1088-1092.

13. Garraway, L.A., Widlund, H.R., Rubin, M.A. et al. (2005), 'Integrative genomic analyses identify MITF as a lineage survival oncogene amplified in malignant melanoma', Nature Vol. 436, pp. 117-122.

14. Staunton, J.E., Slonim, D.K., Coller, H.A. et al. (2001), 'Chemosensitivity prediction by transcriptional profiling', Proc. Natl. Acad. Sci. USA Vol. 98, pp. 10787-10792.

15. Walsh, A.C., Feulner, J.A. and Reilly, A. (2001), 'Evidence for functionally significant polymorphism of human glutamate cysteine ligase catalytic subunit: Association with glutathione levels and drug resistance in the 
National Cancer Institute tumor cell line panel', Toxicol. Sci. Vol. 61, pp. $218-223$.

16. Moisan, F., Longy, M., Robert, J. et al. (2006), 'Identification of gene polymorphisms of human DNA topoisomerase I in the National Cancer Institute panel of human tumour cell lines', Br. J. Cancer Vol. 95, pp. $906-913$.

17. http://dtp.nci.nih.gov.

18. Fang, X., Shao, L., Zhang, H. et al. (2004), 'Web-based tools for mining the NCI databases for anticancer drug discovery', J. Chem. Inf. Comput. Sci. Vol. 44, pp. $249-257$.

19. http://dtp.nci.nih.gov/docs/compare/compare.html.

20. http://dtp.nci.nih.gov/mtargets/download.html.

21. R Development Core Team (2006), 'R: A language and environment for statistical computing'. R Foundation for Statistical Computing, Vienna, Austria.

22. Benjamini, Y. and Hochberg, Y. (1995), 'Controlling the false discovery rate: A practical and powerful approach to multiple testing', J. R. Stat. Soc. [Ser B] Vol. 57, pp. 289-300.

23. http://dtp.nci.nih.gov/docs/cancer/searches/standard_agent.html.

24. Boyd, M.R. (1989), 'Status of the NCI preclinical antitumor drug discovery screen', in: DeVita, V.T., Jr, Hellman, S. and Rosenberg, S.A. (eds), Cancer: Principles and Practice of Oncology (3rd Edn), Lippincott, Philadelphia, PA, pp. 1-12.

25. Draghici, S., Khatri, P., Bhavsar, P. et al. (2003), 'Onto-Tools, the toolkit of the modern biologist: Onto-Express, Onto-Compare, Onto-Design and Onto-Translate', Nucleic Acids Res. Vol. 31, pp. $3775-3781$

26. Draghici, S., Khatri, P., Martins, R.P. et al. (2003), 'Global functional profiling of gene expression', Genomics Vol. 81, pp. 98-104.

27. Khatri, P., Bhavsar, P., Bawa, G. et al. (2004), 'Onto-Tools: An ensemble of web-accessible, ontology-based tools for the functional design and interpretation of high-throughput gene expression experiments', Nucleic Acids Res. Vol. 32, pp. W449-456.

28. Ashburner, M., Ball, C.A., Blake, J.A. et al. (2000), 'Gene Ontology: Tool for the unification of biology. The Gene Ontology Consortium', Nat. Genet. Vol. 25, pp. 25-29.

29. Kanehisa, M. and Goto, S. (2000), 'KEGG: Kyoto encyclopedia of genes and genomes', Nucleic Acids Res. Vol. 28, pp. 27-30.

30. Kanehisa, M., Goto, S., Kawashima, S. et al. (2004), 'The KEGG resource for deciphering the genome', Nucleic Acids Res. Vol. 32, pp. D277-D280.

31. Nielsen, T.O., West, R.B., Linn, S.C. et al. (2002), 'Molecular characterisation of soft tissue tumours: A gene expression study', Lancet Vol. 359, pp. 1301-1307.

32. Tusher, V.G., Tibshirani, R. and Chu, G. (2001), 'Significance analysis of microarrays applied to the ionizing radiation response', Proc. Natl. Acad. Sci. USA, Vol. 98 , pp. 5116-5121.

33. Sobell, H.M. (1985), 'Actinomycin and DNA transcription', Proc. Natl. Acad. Sci. USA, Vol. 82, pp. 5328-5331.
34. Kreft, S.G. and Nassal, M. (2003), 'hRUL138, a novel human RNA-binding RING-H2 ubiquitin-protein ligase', J. Cell Sci. Vol. 116, pp. 605-616.

35. Pray, T.R., Parlati, F., Huang, J. et al. (2002), 'Cell cycle regulatory E3 ubiquitin ligases as anticancer targets', Drug Resist. Updat. Vol. 5, pp. $249-258$.

36. Sun, Y. (2006), 'E3 ubiquitin ligases as cancer targets and biomarkers', Neoplasia Vol. 8, pp. 645-654.

37. Geroldi, D., Aldeghi, A. and Emanuele, E. (2007), 'Perifosine may be of therapeutic usefulness in morbid obese females via inhibition of the PI3K/Akt signaling pathway', Med. Hypotheses Vol. 68, p. 236.

38. Elrod, H.A., Lin, Y.D., Yue, P. et al. (2007), 'The alkylphospholipid perifosine induces apoptosis of human lung cancer cells requiring inhibition of Akt and activation of the extrinsic apoptotic pathway', Mol. Cancer Ther. Vol. 6, pp. 2029-2038.

39. Gajate, C. and Mollinedo, F. (2007), 'Edelfosine and perifosine induce selective apoptosis in multiple myeloma by recruitment of death receptors and downstream signaling molecules into lipid rafts', Blood Vol. 109, pp. 711-719.

40. Nyakern, M., Cappellini, A., Mantovani, I. et al. (2006), 'Synergistic induction of apoptosis in human leukemia $\mathrm{T}$ cells by the Akt inhibitor perifosine and etoposide through activation of intrinsic and Fas-mediated extrinsic cell death pathways', Mol. Cancer Ther. Vol. 5, pp. $1559-1570$.

41. Zhang, W., Duan, S., Kistner, E.O. et al. (2008), 'Evaluation of genetic variation contributing to differences in gene expression between populations', Am. J. Hum. Genet. Vol. 82, pp. 631-640.

42. Zhang, W., Ratain, M.J. and Dolan, M.E. (2008), 'The HapMap Resource is providing new insights into ourselves and its application to pharmacogenomics', Bioinform. Biol. Insights Vol. 2, pp. $15-23$.

43. Munshi, N.C., Hideshima, T., Carrasco, D. et al. (2004), 'Identification of genes modulated in multiple myeloma using genetically identical twin samples', Blood Vol. 103, pp. 1799-1806.

44. Richardson, P., Lonial, S., Jakubowiak, A. et al. (2007), 'Multi-center phase II study of perifosine (KRX-0401) alone and in combination with dexamethasone (dex) for patients with relapsed or relapsed/refractory multiple myeloma (MM): Promising activity as combination therapy with manageable toxicity', ASH Annual Meeting Abstracts Vol. 110, p. 1164.

45. Skubitz, K.M. and Skubitz, A.P. (2004), 'Characterization of sarcomas by means of gene expression', J. Lab. Clin. Med. Vol. 144, pp. $78-91$.

46. Scherf, U., Ross, D.T., Waltham, M. et al. (2000), 'A gene expression database for the molecular pharmacology of cancer', Nat. Genet. Vol. 24, pp. 236-244.

47. Ross, D.T., Scherf, U., Eisen, M.B. et al. (2000), 'Systematic variation in gene expression patterns in human cancer cell lines', Nat. Genet. Vol. 24, pp. $227-235$ 
Supplementary Table Ia. A majority of perifosine-specific gene expression levels are associated with the cytotoxicity of edelfosine

\begin{tabular}{|c|c|c|c|c|c|}
\hline Symbol & $\begin{array}{l}\text { Perifosine } \\
\text { ( } p \text {-value) }\end{array}$ & $\begin{array}{l}\text { Edelfosine } \\
\text { ( } p \text {-value) }\end{array}$ & $\begin{array}{l}\text { Perifosine } \\
\text { (r-value) }\end{array}$ & $\begin{array}{l}\text { Edelfosine } \\
\text { (r-value) }\end{array}$ & Notes \\
\hline \multicolumn{6}{|l|}{ NS-cDNA } \\
\hline ATF2 & 0.0000 & 0.0075 & -0.560 & -0.348 & Significant \\
\hline TRA2A & 0.0008 & 0.0005 & -0.438 & -0.456 & Significant \\
\hline ETS2 & 0.0005 & 0.0004 & -0.438 & -0.449 & Significant \\
\hline UBE2D3 & 0.0009 & 0.0026 & -0.419 & -0.382 & Significant \\
\hline VEGFB & 0.0006 & 0.0001 & 0.443 & 0.502 & Significant \\
\hline ANP32A & 0.0002 & 0.0003 & 0.492 & 0.469 & Significant \\
\hline \multicolumn{6}{|l|}{ GL-U95 } \\
\hline REG4 & 0.0000 & 0.0004 & -0.579 & -0.443 & Significant \\
\hline SLCO4AI & 0.0000 & 0.0060 & -0.518 & -0.351 & Significant \\
\hline RPLI8A & 0.0000 & 0.0093 & -0.500 & -0.333 & Significant \\
\hline OAZ2 & 0.0000 & 0.0018 & 0.527 & 0.394 & Significant \\
\hline DZIP3 & 0.0000 & 0.0001 & 0.580 & 0.478 & Significant \\
\hline \multicolumn{6}{|l|}{ NP-U95 } \\
\hline STK39 & 0.0001 & 0.0004 & -0.479 & -0.449 & Significant \\
\hline FAM $32 A$ & 0.0002 & 0.0529 & -0.460 & -0.253 & Marginal \\
\hline MAPKAPK 3 & 0.0003 & 0.0920 & -0.454 & -0.221 & Marginal \\
\hline$R A B 8 A$ & 0.0005 & 0.0018 & $-0.44 I$ & -0.399 & Significant \\
\hline STKI TB & 0.0006 & 0.0243 & -0.435 & -0.293 & Significant \\
\hline TCF3 & 0.0006 & 0.0054 & -0.435 & -0.358 & Significant \\
\hline PARP4 & 0.0006 & 0.0000 & -0.433 & -0.519 & Significant \\
\hline PSMA2 & 0.0006 & 0.0060 & -0.432 & -0.354 & Significant \\
\hline DGKE & 0.0007 & 0.0019 & -0.429 & -0.396 & Significant \\
\hline PVTI & 0.0010 & 0.0018 & 0.418 & 0.398 & Significant \\
\hline ELOVL2 & 0.0009 & 0.0005 & 0.419 & 0.438 & Significant \\
\hline SMARCA3 & 0.0009 & 0.0038 & 0.420 & 0.371 & Significant \\
\hline USP6 & 0.0007 & 0.0094 & 0.428 & 0.335 & Significant \\
\hline NFATC4 & 0.0005 & 0.0305 & 0.437 & 0.282 & Significant \\
\hline$I G F I R$ & 0.0005 & 0.0570 & 0.437 & 0.249 & Marginal \\
\hline POU4FI & 0.0005 & 0.0023 & 0.439 & 0.390 & Significant \\
\hline
\end{tabular}


Supplementary Table Ia. Continued

\begin{tabular}{|c|c|c|c|c|c|}
\hline Symbol & $\begin{array}{l}\text { Perifosine } \\
\text { ( } p \text {-value) }\end{array}$ & $\begin{array}{l}\text { Edelfosine } \\
\text { ( } p \text {-value) }\end{array}$ & $\begin{array}{l}\text { Perifosine } \\
\text { ( } r \text {-value) }\end{array}$ & $\begin{array}{l}\text { Edelfosine } \\
\text { (r-value) }\end{array}$ & Notes \\
\hline PDLIM3 & 0.0005 & 0.0058 & 0.440 & 0.355 & Significant \\
\hline CBS & 0.0004 & 0.0094 & 0.443 & 0.336 & Significant \\
\hline$A R M C X 2$ & 0.0004 & 0.0008 & 0.447 & 0.425 & Significant \\
\hline OPHNI & 0.0003 & 0.0194 & 0.459 & 0.304 & Significant \\
\hline ZNF609 & 0.0002 & 0.0091 & 0.462 & 0.337 & Significant \\
\hline ATNI & 0.0001 & 0.0754 & 0.474 & 0.233 & Marginal \\
\hline DZIP3 & 0.0001 & 0.0093 & 0.479 & 0.336 & Significant \\
\hline PPBPL2 & 0.0001 & 0.0081 & 0.487 & 0.342 & Significant \\
\hline MPDZ & 0.0000 & 0.0001 & 0.534 & 0.498 & Significant \\
\hline SKIV2L & 0.0000 & 0.0007 & 0.557 & 0.427 & Significant \\
\hline GABRG3 & 0.0000 & 0.0000 & 0.601 & 0.533 & Significant \\
\hline
\end{tabular}

Supplementary Table Ib. The perifosine-specific SNPs are associated with the cytotoxicity of edelfosine

\begin{tabular}{|c|c|c|c|c|c|}
\hline dbSNP & $\begin{array}{l}\text { Perifosine } \\
\text { ( } p \text {-value) }\end{array}$ & $\begin{array}{l}\text { Perifosine } \\
\text { (r-value) }\end{array}$ & $\begin{array}{l}\text { Edelfosine } \\
\text { ( } p \text {-value) }\end{array}$ & $\begin{array}{l}\text { Edelfosine } \\
\text { (r-value) }\end{array}$ & Notes \\
\hline rs4236669 & $2.80 \mathrm{E}-07$ & 0.64 & I.75E-03 & 0.42 & Significant \\
\hline rs|468400 & $8.80 \mathrm{E}-07$ & 0.62 & $6.27 \mathrm{E}-04$ & 0.46 & Significant \\
\hline rsI345938 & $2.60 \mathrm{E}-06$ & 0.58 & $3.66 \mathrm{E}-05$ & 0.52 & Significant \\
\hline
\end{tabular}


Supplementary Table 2. Genes whose expression levels were associated with the cytotoxicity of perifosine $\left(F_{D D R}<0.10\right)$ but were not perifosine specific

\begin{tabular}{|c|c|c|c|c|}
\hline Symbol & Gene title & $r$ & $p$ & $\begin{array}{l}\text { Control } \\
\text { total }^{\mathrm{a}}\end{array}$ \\
\hline \multicolumn{5}{|l|}{ GL-U95 } \\
\hline FNBP3 & Formin-binding protein 3 & -0.53 & $3.5 \mathrm{E}-05$ & 75 \\
\hline MOBKL2A & $\begin{array}{l}\text { MOBI, Mps One Binder kinase } \\
\text { activator-like } 2 \mathrm{~A} \text { (yeast) }\end{array}$ & -0.50 & $5.5 \mathrm{E}-05$ & 43 \\
\hline TP53INP2 & $\begin{array}{l}\text { Tumour protein p53 inducible nuclear } \\
\text { protein } 2\end{array}$ & 0.51 & 3.9E-05 & 24 \\
\hline FBX044 & F-box protein 44 & 0.52 & 2.4E-05 & 53 \\
\hline$T M F I$ & TATA element modulatory factor I & 0.53 & I.7E-05 & 57 \\
\hline$D D \times 39$ & $\begin{array}{l}\text { DEAD (Asp-Glu-Ala-Asp) box } \\
\text { polypeptide } 39\end{array}$ & -0.49 & 7.3E-05 & 22 \\
\hline MRPL23 & Mitochondrial ribosomal protein L23 & -0.49 & 8.7E-05 & 2 \\
\hline RPS24 & Ribosomal protein $\$ 24$ & -0.47 & I.9E-04 & 21 \\
\hline$L B R$ & Lamin B receptor & -0.47 & 2.0E-04 & 73 \\
\hline ERCC5 & $\begin{array}{l}\text { Excision repair cross-complementing } \\
\text { rodent repair deficiency, complementation } \\
\text { group } 5\end{array}$ & -0.47 & 2.0E-04 & 11 \\
\hline ICAM3 & Intercellular adhesion molecule 3 & -0.44 & 5.IE-04 & 43 \\
\hline SNRPF & $\begin{array}{l}\text { Small nuclear ribonucleoprotein } \\
\text { polypeptide } F\end{array}$ & -0.44 & $5.2 \mathrm{E}-04$ & 83 \\
\hline$S H 2 D / A$ & $\begin{array}{l}\text { SH2 domain protein IA, Duncan's disease } \\
\text { (lymphoproliferative syndrome) }\end{array}$ & -0.44 & $5.8 \mathrm{E}-04$ & 61 \\
\hline KIR3DLI & $\begin{array}{l}\text { Killer cell immunoglobulin-like receptor, } \\
\text { three domains, long cytoplasmic tail, I }\end{array}$ & -0.43 & 7.3E-04 & 76 \\
\hline RPL35 & Ribosomal protein L35 & -0.42 & 8.IE-04 & 47 \\
\hline NUPL2 & Nucleoporin-like 2 & -0.42 & 8.8E-04 & I \\
\hline PTMA & Prothymosin, alpha (gene sequence 28 ) & -0.42 & $9.0 \mathrm{E}-04$ & 33 \\
\hline COROIA & Coronin, actin-binding protein, IA & -0.42 & $9.3 \mathrm{E}-04$ & 104 \\
\hline
\end{tabular}


Supplementary Table 2. Continued

\begin{tabular}{|c|c|c|c|c|}
\hline Symbol & Gene title & $r$ & $p$ & $\begin{array}{l}\text { Control } \\
\text { total }^{\mathrm{a}}\end{array}$ \\
\hline LCNI & Lipocalin I (tear prealbumin) & -0.42 & $9.3 \mathrm{E}-04$ & 21 \\
\hline POLE3 & $\begin{array}{l}\text { Polymerase (DNA directed), epsilon } 3 \\
\text { (p } 17 \text { subunit) }\end{array}$ & -0.42 & $9.2 \mathrm{E}-04$ & 31 \\
\hline RPS27A & Ribosomal protein S27a & -0.42 & $9.4 \mathrm{E}-04$ & 79 \\
\hline TRIMI4 & Tripartite motif-containing 14 & -0.42 & $9.3 \mathrm{E}-04$ & 60 \\
\hline LHFPL2 & Lipoma HMGIC fusion partner-like 2 & 0.42 & I.0E-03 & 99 \\
\hline DOK5 & Docking protein 5 & 0.42 & $9.5 \mathrm{E}-04$ & I \\
\hline EIF4GI & $\begin{array}{l}\text { Eukaryotic translation initiation factor } 4 \\
\text { gamma, I }\end{array}$ & 0.42 & $9.6 \mathrm{E}-04$ & 28 \\
\hline RGSI9 & $\begin{array}{l}\text { Regulator of G-protein signalling } 19 \\
\text { interacting protein I }\end{array}$ & 0.42 & $9.2 \mathrm{E}-04$ & 116 \\
\hline COPB2 & $\begin{array}{l}\text { Coatomer protein complex, subunit beta } \\
2 \text { (beta prime) }\end{array}$ & 0.42 & $8.9 \mathrm{E}-04$ & I \\
\hline TLE2 & $\begin{array}{l}\text { Transducin-like enhancer of split } 2 \text { (E(spl) } \\
\text { homologue, Drosophila) }\end{array}$ & 0.42 & $9.0 \mathrm{E}-04$ & 4 \\
\hline ITGA7 & Integrin, alpha 7 & 0.42 & 8.6E-04 & 13 \\
\hline SEMA3C & $\begin{array}{l}\text { Sema domain, immunoglobulin domain } \\
\text { (lg), short basic domain, secreted, } \\
\text { (semaphorin) 3C }\end{array}$ & 0.42 & $8.2 \mathrm{E}-04$ & 22 \\
\hline$S / 00 A / 3$ & SI00 calcium binding protein $\mathrm{A} / 3$ & 0.43 & $7.8 \mathrm{E}-04$ & 88 \\
\hline FLOTI & Flotillin I & 0.43 & $6.5 \mathrm{E}-04$ & 2 \\
\hline MLFI & Myeloid leukemia factor I & 0.43 & $6.0 \mathrm{E}-04$ & 11 \\
\hline ARHGEFII & $\begin{array}{l}\text { Rho guanine nucleotide exchange factor } \\
\text { (GEF) II }\end{array}$ & 0.44 & $5.5 \mathrm{E}-04$ & 9 \\
\hline COLI5AI & Collagen, type XV, alpha I & 0.44 & 4.9E-04 & I \\
\hline DAGI & $\begin{array}{l}\text { Dystroglycan I (dystrophin-associated } \\
\text { glycoprotein I) }\end{array}$ & 0.44 & 4.9E-04 & 118 \\
\hline IFNA / 4 & Interferon alpha 14 & 0.44 & $4.8 \mathrm{E}-04$ & 2 \\
\hline PHLDBI & $\begin{array}{l}\text { Pleckstrin homology-like domain, family B, } \\
\text { member I }\end{array}$ & 0.44 & $4.5 \mathrm{E}-04$ & 12 \\
\hline PTPRS & $\begin{array}{l}\text { Protein tyrosine phosphatase, receptor } \\
\text { type S }\end{array}$ & 0.45 & 4.0E-04 & 2 \\
\hline SASHI & SAM and $\mathrm{SH} 3$ domain containing I & 0.45 & 4.IE-04 & 52 \\
\hline$A C V R I B$ & Activin A receptor, type IB & 0.45 & $3.2 \mathrm{E}-04$ & 18 \\
\hline CTNNAI & $\begin{array}{l}\text { Catenin (cadherin-associated protein), } \\
\text { alpha I, } 102 \mathrm{kDa}\end{array}$ & 0.46 & 3.0E-04 & 30 \\
\hline
\end{tabular}


Supplementary Table 2. Continued

\begin{tabular}{|c|c|c|c|c|}
\hline Symbol & Gene title & $\boldsymbol{r}$ & $p$ & $\begin{array}{l}\text { Control } \\
\text { total }^{\mathrm{a}}\end{array}$ \\
\hline IL6ST & $\begin{array}{l}\text { Interleukin } 6 \text { signal transducer (gp I30, } \\
\text { oncostatin M receptor) }\end{array}$ & 0.46 & $2.9 \mathrm{E}-04$ & 68 \\
\hline ATP6VID & $\begin{array}{l}\text { ATPase, } \mathrm{H}+\text { transporting, lysosomal } \\
34 \mathrm{kDa}, \mathrm{VI} \text { subunit } \mathrm{D}\end{array}$ & 0.46 & $2.5 \mathrm{E}-04$ & 2 \\
\hline SUOX & Sulphite oxidase & 0.46 & 2.IE-04 & 58 \\
\hline TFAP2A & $\begin{array}{l}\text { Transcription factor AP-2 alpha (activating } \\
\text { enhancer binding protein } 2 \text { alpha) }\end{array}$ & 0.48 & I.3E-04 & 51 \\
\hline GRINA & $\begin{array}{l}\text { Glutamate receptor, ionotropic, } \mathrm{N} \text {-methyl } \\
\text { D-asparate-associated protein I } \\
\text { (glutamate binding) }\end{array}$ & 0.49 & $9.3 \mathrm{E}-05$ & I \\
\hline$A B C B 6$ & $\begin{array}{l}\text { ATP-binding cassette, sub-family B (MDR/ } \\
\text { TAP), member } 6\end{array}$ & 0.49 & $8.2 \mathrm{E}-05$ & 8 \\
\hline CTSF & Cathepsin F & 0.49 & 7.4E-05 & 9 \\
\hline VEGFB & Vascular endothelial growth factor B & 0.50 & 4.6E-05 & 6 \\
\hline GGCX & Gamma-glutamyl carboxylase & 0.52 & 2.IE-05 & 23 \\
\hline LAPTM4B & $\begin{array}{l}\text { Lysosomal-associated protein } \\
\text { transmembrane } 4 \text { beta }\end{array}$ & 0.53 & I.6E-05 & 84 \\
\hline FYN & Sialidase I (lysosomal sialidase) & 0.55 & $6.3 \mathrm{E}-06$ & 59 \\
\hline \multicolumn{5}{|l|}{ NS-cDNA } \\
\hline$L B R$ & Lamin B receptor & -0.47 & I.3E-04 & I \\
\hline TRA2A & Transformer-2 alpha & -0.44 & $8.3 \mathrm{E}-04$ & 13 \\
\hline ETS2 & $\begin{array}{l}\text { V-ets erythroblastosis virus E26 oncogene } \\
\text { homolog } 2 \text { (avian) }\end{array}$ & -0.44 & 5.3E-04 & 30 \\
\hline UBE2D3 & $\begin{array}{l}\text { Ubiquitin-conjugating enzyme E2D } 3 \\
\text { (UBC4/5 homologue, yeast) }\end{array}$ & -0.42 & $8.5 \mathrm{E}-04$ & 4 \\
\hline RRMI & Ribonucleotide reductase MI polypeptide & -0.41 & $9.8 \mathrm{E}-04$ & I \\
\hline ATP6VICI & $\begin{array}{l}\text { ATPase, } \mathrm{H}+\text { transporting, lysosomal } \\
42 \mathrm{kDa}, \mathrm{VI} \text { subunit } \mathrm{C} \text {, isoform I }\end{array}$ & 0.42 & 7.7E-04 & 51 \\
\hline VEGFB & Vascular endothelial growth factor B & 0.44 & $6.3 \mathrm{E}-04$ & 57 \\
\hline$R D X$ & Radixin & 0.45 & $4.2 \mathrm{E}-04$ & 29 \\
\hline$A P O D$ & Apolipoprotein D & 0.45 & 3.IE-04 & 3 \\
\hline PTMS & Parathymosin & 0.47 & I.8E-04 & 2 \\
\hline
\end{tabular}

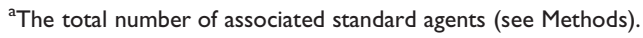




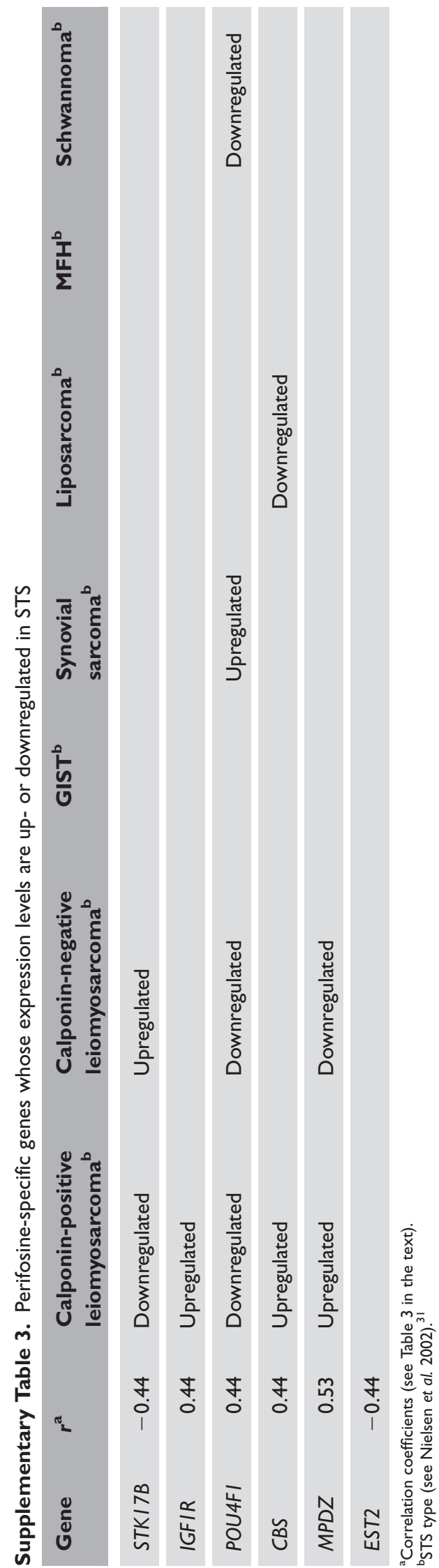

